\title{
Gastrointestinal transit of extruded or pelletized diets in pacu fed distinct inclusion levels of lipid and carbohydrate
}

\author{
Claucia Aparecida Honorato(1), Luciana Cristina de Almeida ${ }^{(2)}$, Cleujosí da Silva Nunes ${ }^{(3)}$, \\ Elma Neide Vasconcelos Martins Carrilho(4) and Gilberto Moraes ${ }^{(2)}$
}

\begin{abstract}
${ }^{(1)}$ Centro Universitário da Grande Dourados, Faculdade de Ciências Biológicas e da Saúde, Hospital Veterinário, Rua Balbina de Matos, o 2.121, Bairro Jardim, CEP 79824-900 Dourados, MS, Brazil. E-mail: clauciahonorato@yahoo.com.br (2)Universidade Federal de São Carlos (Ufscar), Departamento de Genética e Evolução, Laboratório de Bioquímica Adaptativa, Rodovia Washington Luiz, Km 235, CEP 13565-905 São Carlos, SP, Brazil. E-mail: recadolucianaalmeida@gmail.com, gibaufscar@gmail.com ${ }^{(3)}$ Universidade Estadual do Mato Grosso do Sul, Laboratório de Ictioparasitologia, Rodovia Aquidauana, CEP 79200-000 Aquidauana, MS, Brazil. E-mail: cleujosi@yahoo.com.br (4)Ufscar, Departamento de Ciências da Natureza, Matemática e Educação, Laboratório de Materiais Poliméricos e Biossorventes, Rodovia Anhanguera, SP-330, Km 174, CEP $13600-970$ Araras, SP, Brazil. E-mail: elma.carrilho@gmail.com
\end{abstract}

\begin{abstract}
The objective of this work was to evaluate the effect of pelletized or extruded diets, with different levels of carbohydrate and lipid, on the gastrointestinal transit time (GITT) and its modulation in pacu (Piaractus mesopotamicus). One hundred and eighty pacu juveniles were fed with eight isonitrogenous diets containing two carbohydrate levels (40 and 50\%) and two lipid levels (4 and $8 \%$ ). Four diets were pelletized and four were extruded. Carbohydrate and lipid experimental levels caused no changes to the bolus transit time. However, the bolus permanence time was related to diet processing. Fish fed pelletized diets exhibited the highest gastrointestinal transit time. Regression analysis of bolus behavior for pelletized and extruded diets with $4 \%$ lipid depicted different fits. GITT regression analysis of fish fed $8 \%$ lipid was fitted to a cubic equation and displayed adjustments of food permanence, with enhanced utilization of the diets, either with extruded or pelletized diets. GITT of fish fed extruded diets with $4 \%$ lipid was adjusted to a linear equation. The GITT of pacu depends on the diet processing and is affected by dietary levels of lipid and carbohydrate.
\end{abstract}

Index terms: Piaractus mesopotamicus, carbohydrate, lipid, starch gelatinization, viscosity.

\section{Trânsito gastrintestinal de dietas extrusadas ou peletizadas em pacu alimentado com níveis distintos de inclusão de lipídios e carboidratos}

\begin{abstract}
Resumo - O objetivo deste trabalho foi avaliar o efeito de dietas peletizadas ou extrusadas, com diferentes níveis de carboidrato e lipídio, sobre o tempo de trânsito gastrointestinal e sua modulação em pacu (Piaractus mesopotamicus). Cento e oitenta juvenis de pacu foram alimentados com oito dietas isoproteicas com dois níveis de carboidratos (40 e 50\%) e dois níveis de lipídeos (4 e 8\%). Quatro dietas foram peletizadas e quatro extrusadas. Os níveis experimentais de carboidrato e lipídeo não alteraram o tempo de passagem do bolo alimentar. Entretanto, o tempo de permanência do bolo alimentar foi dependente do processamento aplicado à dieta. Os peixes alimentados com dietas peletizadas apresentaram o maior tempo de trânsito gastrointestinal (TTGI). A análise de regressão do comportamento do bolo alimentar para dietas peletizadas e extrusadas com $4 \%$ de lipídeo mostraram diferentes ajustes. A análise de regressão do TTGI de peixes alimentados com $8 \%$ de lipídios ajustou-se a uma equação cúbica e mostrou ajustes na permanência do alimento, com maior aproveitamento das dietas, quer com dietas extrusadas ou peletizadas. O TTGI dos peixes que receberam dietas extrusadas com $4 \%$ de lipídeos ajustou-se a uma equação linear. O TTGI de pacu depende do processamento da dieta e é afetado pelos níveis de lipídios e carboidratos na dieta.
\end{abstract}

Termos para indexação: Piaractus mesopotamicus, carboidrato, lipídio, gelatinização do amido, viscosidade.

\section{Introduction}

A regulatory factor on feed transformation along the length of the digestive tract is the feed transit time and absorption. In fish, the motility of digestive system is associated with the diet composition (Fabregat et al., 2011), food consumption (Silva et al., 2003), and temperature acclimatization (Dias-Koberstein et al., 2005). The transit time depends on the gastric volume, which is the primary stimulus to motility increase (Mayumeoshiro et al., 2012).

Bolus retention influences both the animal digestion and the absorption efficiency, on account of food exposure period (Mayumeoshiro et al., 2012). Fish 
fed diets which remain in the digestive tract for short periods may have low-digestion and absorption rates of nutrients (Kitagima \& Fracalossi, 2010). Besides, feed permanence for long time in the digestive tract may decrease animal performance, impairing digestion or absorption, for avoiding a free space to be stuffed by new feed (Kubtiza, 2013). Determination of the bolus gastrointestinal transit time is pivotal to evaluate feed processing and gauge the extent of feed digestion (Oliveira et al., 2007). Models of bolus movement behavior intend to represent and to predict some biological events, such as the transit rate of particles and fluids (Pereira et al., 2005). Equation models allow us to obtain estimates of transit kinetic parameters to different diets and their utilization dynamics (Mayumeoshiro et al., 2012). Then, evaluation of digestive behavior by the gastrointestinal transit time is a valuable tool for fish nutrition studies.

The use of dietary carbohydrate sources in fish nutrition raises the expectation towards protein sparing (Abmoradi \& Carneiro, 2007; Yang et al., 2013). However, the use of carbohydrate by fish depends mainly on its source and on the amylose: amylopectin ratio (González-Félix et al., 2010), which is associated to the molecule complexity (Venou et al., 2003). It is widely known that cellulose decreases the emptying time of the gastrointestinal tract (Meurer et al., 2003), whereas the opposite occurs to some other polysaccharides (Wenk, 2011). Besides, some substances such as hemicellulose or pectin can increase the bolus viscosity, increasing the resistance of propulsive contractions of the digestive tract (Meurer et al., 2003). Some studies report a low capacity of fish to make use of dietary raw starch as compared with gelatinized one (Venou et al., 2003; González-Félix et al., 2010).

Modifications in the carbohydrate structure have been attempted to improve the use of dietary sugars by fish. Such changes can be reached through processing techniques, among which, extrusion and pelletization are the most used in food manufacturing for aquatic animals. These techniques can bring about beneficial modifications in starch structure (Vieira et al., 2005). Extrusion is a process by which a set of mixed and moistened ingredients, under high temperatures, are forced through an opening in a perforated plate or die with a specific design, and then they are cut to a specified size by blades. Extrusion is considered an efficient process to expand starch in the food sources (Booth et al., 2013). However, this process also causes protein denaturation, facilitating the enzymatic hydrolysis into the digestive tract (Venou et al., 2003). Extrusion can also trigger serial events such as starch gelatinization, inactivation of antinutritional factors, formation of amylose-lipid complexes, mineral chelation, destruction of vitamins, minimization of the Maillard's reaction, and slowing of fat rancidification (Zongjia \& Hardy, 2003). Pelletization is a mechanical process by which compaction is done through an enforced passage for ingredient mixture, which is finally grinded across a pelletizer sieve. Over this process, there is partial gelatinization of starch, which facilitates ingredients agglutination, and produces high-density materials. This process allows us to obtain pellets with higher ingredient equality, lower feeding selectivity, and reduction of nutrient waste by leaching (Honorato et al., 2012).

Neotropical freshwater fish pacu Piaractus mesopotamicus (Holmberg, 1887) is a teleost species introduced and widely reared in warm water fish farms in South America. It displays a high potentiality to intense farming for its rusticity, high-growth rates and high-quality fillets. It is easily adapted to artificial feeding and has been widely investigated concerning the diet composition employed in artificial rearing (Abimorad \& Carneiro, 2007). For fish feeding, the ideal diet processing, either pelletization or extrusion, depends on previous determinations regarding its effects on the gastrointestinal transit time (GITT).

The objective of this work was to evaluate the effects of pelletized or extruded diets, with different levels of carbohydrate and lipid, on the GITT and its modulation in pacu.

\section{Materials and Methods}

This experimental work was carried out in the nutritional laboratory of aquatic organisms of the Universidade do Estado de São Paulo (Caunesp), Jaboticabal, SP,Brazil $\left(21^{\circ} 15^{\prime} \mathrm{S}, 48^{\circ} 18^{\prime} \mathrm{W}\right)$. Eightbatches of isonitrogenous diets were formulated to contain $26.7 \pm 0.7 \%$ crude protein $(\mathrm{CP})$, two carbohydrate levels (40 and 50\%), and two lipid levels (4 and 8\%). Four of those batches were pelletized, and the remaining ones were extruded (Table 1). To evaluate the GITT, two other diets from each isonitrogenous one were 
formulated with $0.5 \%$ (chromium (III) oxide) $\mathrm{Cr}_{2} \mathrm{O}_{3}$, and $0.5 \%$ (titanium dioxide) $\mathrm{TiO}_{2}$ (Dias-Koberstein et al., 2005).

Diet extrusion was undertaken with a simple-screw extruder (Extrutec, São Carlos, SP, Brazil), with $10 \mathrm{~kg}$ per hours nominal capacity. Pelletization of diets took place in a laboratory pelletizer (California Pellet Mill, São Paulo, SP, Brazil). Pellet sizes ranged between $1.2-1.5 \mathrm{~mm}$ diameter and $1.5-3.0 \mathrm{~mm}$ length. The ingredients were analyzed to determine the food composition (Horwitz, 2000).

Gastrointestinal transit time assays were carried out with one hundred and eighty pacu juveniles weighing $69.6 \pm 17.9 \mathrm{~g}$. Fish were randomly distributed into 12 cubic asbestos-cement tanks, with $150 \mathrm{~L}$ capacity. These tanks

Table 1. Ingredients and chemical composition of experimental diets for pacu (Piaractus mesopotamicus).

\begin{tabular}{lccccc}
\hline \multirow{2}{*}{$\begin{array}{l}\text { Ingredient } \\
\text { F })\end{array}$} & \multicolumn{2}{c}{$40 \%$ carbohydrate } & & \multicolumn{2}{c}{$50 \%$ carbohydrate } \\
\cline { 2 - 3 } \cline { 5 - 6 } & $4 \%$ lipid & $8 \%$ lipid & & $4 \%$ lipid & $8 \%$ lipid \\
\hline Fish meal & 10.4 & 10.4 & & 10.4 & 10.4 \\
Soybean meal & 31.0 & 13.0 & & 25.5 & 11.5 \\
Full-fat toasted soybean & 47.0 & 22.0 & & 75.0 & 20.8 \\
Corn & 26.9 & 29.9 & & 25.5 & 25.0 \\
Corn starch & - & - & 8.9 & 12.5 \\
Wheat flour & - & 2.0 & 9.0 & 8.0 \\
Wheat meal & 6.5 & 8.0 & 2.6 & 2.0 \\
Grinded rice & 8.5 & 7.0 & 8.0 & 7.9 \\
Soybean oil & 5.0 & 4.0 & - & 9.0 \\
Microfine cellulose & 10.5 & 6.3 & & 1.6 & - \\
Mineral and vitamin ${ }^{(1)}$ & 10.0 & 10.0 & & 10.0 & 10.0 \\
\hline Chemical composition $\left(\mathrm{g} \cdot \mathrm{kg}^{-1}\right)$ & & & & \\
Dry matter & 89.4 & 89.4 & 88.7 & 89.6 \\
Crude protein & 27.0 & 27.5 & 26.0 & 25.6 \\
Crude fibre & $(2)$ & 13.1 & 8.6 & 4.0 & 1.9 \\
Lipid & 4.0 & 8.0 & 4.1 & 8.0 \\
Mineral matter & 5.2 & 5.4 & 5.3 & 5.0 \\
Carbohydrate & $(3)$ & 40.1 & 40.0 & 500 & 492 \\
Crude energy $\left(\mathrm{MJ}^{2} \cdot \mathrm{kg}^{-1}\right)$ & 16 & 17 & 17 & 18 \\
Digestible protein & $(4)$ & 22.1 & 22.1 & 21.9 & 22.2 \\
\hline
\end{tabular}

(1)Rovimix supplement (DSM Nutritional Products AG, Kaiseraugst, Switzerland) (ingredients per kg): vitamins: A, 55,000,000 IU; D, 35,200,000 IU; E, 55,000 IU; K, 351,000.0 mg; B1 (thiamine), 51,500.0 mg; B2 (riboflavin), 51,500.0 mg; B6 (pyridoxine), 51,500.0 mg; $\mathrm{B}_{12}, 54,000.0 \mu \mathrm{g}$; , $515,000.0 \mathrm{mg}$; folic acid, 5,500.0 mg; pantothenic acid, 54,000.0 mg; BHT, $512.25 \mathrm{~g}$; biotin, $550.0 \mathrm{mg}$; inositol, $51,000.0 \mathrm{mg}$; nicotinamide , $57,000.0 \mathrm{mg}$; choline, $540.0 \mathrm{~g}$; $\mathrm{Co}, 510.0 \mathrm{mg}$; $\mathrm{Cu}, 5,500.0 \mathrm{mg}$; Fe, 55,000.0 mg; I, $550.0 \mathrm{mg}$; Mn, $51,500.0 \mathrm{mg}$; Se, $510.0 \mathrm{mg}$; Zn, 55,000.0 mg; vehicle q.s.p., $51,000.0$ g. ${ }^{(2)}$ Crude fibre, appropriate for pacu (Abimorad \& Carneiro (2007). ${ }^{(3)}$ Carbohydrate $=$ dry matter $-($ crude protein - lipid - crude fiber - mineral matter). ${ }^{(4)}$ Digestibility ingredients for pacu, according to Abimorad \& Carneiro (2007). were supplied with artesian well water (approximately 2 $\mathrm{L} \mathrm{min}^{-1}$ flow rate) and continuous aeration. The drainage system was directly set at the bottom, facilitating excreta and food residue removal, and the tanks were siphoned weekly to improve environmental conditions. Water temperature $\left(29^{\circ} \mathrm{C}\right)$ and dissolved oxygen $(5.6 \pm 0.42 \mathrm{mg}$ $\left.\mathrm{L}^{-1}\right)$ were monitored dayly; $\mathrm{pH}(7.4 \pm 0.1)$, alkalinity $\left(5.6 \pm 0.42 \mathrm{mg} \mathrm{L}^{-1}\right)$, and conductivity $\left(190.5 \pm 1.5 \mu \mathrm{S} \mathrm{cm}^{-1}\right)$ were measured weekly.

Fish were fed with diets containing $0.5 \% \mathrm{Cr}_{2} \mathrm{O}_{3}$ (green) twice a day, for 10 days (Table 1). At the GITT test beginning, fish were fed with the same diet, but $0.5 \% \mathrm{TiO}_{2}$ (white) replaced the green pigment. White diets were offered for four hours, every hour. Total food was supplied at $10 \%$ live weight. Six hours after the last feeding, fish were transferred to $80-\mathrm{L}$ conic cylinder tanks with a Guelph's system, and feces were collected every $60 \mathrm{~min}$ to avoid nutrient leaching and frozen until chromium oxide quantification (Furukawa \& Tsukahara, 1966; Honorato et al., 2012). The shift of feces color from green to full white, due to the presence of chemical markers, was used to estimate the diet GITT (Dias-Kobersteinet al., 2005).

GITT was determined following a completely randomized design, with eight treatments, in a $2 \times 2 \times 2$ factorial arrangement. It included two levels of carbohydrate (40 and 50\%), two levels of lipids (4 and $8 \%$ ), and two diet processing methods (pelletization and extrusion), with three replicates. Data were analyzed through analysis of variance parametric test, followed by Tukey's post-test, at 5\% of probability.

Modulations in the GITT were evaluated through the sequential depletion of the gastrointestinal tract of each diet (P40/4, P40/8, P50/4, P50/4, E40/4, E40/8, $\mathrm{E} 50 / 4, \mathrm{E} 50 / 8$ ). Feces were collected every hour (at 6 , $8,10,11,12,13,14,15,16,17,18$, and $19 \mathrm{~h}$ ), and oxide was quantified (Honorato et al., 2012). Modulations of GITT were analyzed by polynomial regression. The equations were used to describe the GITT depletion modulation.

\section{Results and Discussion}

The gastrointestinal transit time of pacu was not changed either by carbohydrate or lipid dietary levels; however, diet processing altered the bolus permanence time into the digestive tract (Table 2). GITT values were higher in fish fed pelletized diets than in those fed extruded diets (Figure 1). Such physiological 
trait has been reported for other species (Abimorad $\&$ Carneiro, 2007). The digestive system of pacu is functionally altered by changes in the complexity of dietary carbohydrates (Fabregat et al., 2011). Feeding with gelatinized starch increases the availability of energy in diets for Salmo salar (Young et al., 2006) and Sparus aurata (Venou et al., 2003). Complex, dietary carbohydrate intake results in a decreased capacity of nutrient utilization by fish (Booth et al., 2013). Extruded diets are reported as exhibiting starch gelatinization levels higher than those observed for pelletized diets (Honorato et al., 2012). Such gelatinization would decrease the viscosity degree of diet and reduce the transit time in pacu fed extruded diets. Additionally, increase of nutrients bioavailability, in consequence of the extrusion process, can influence the carbohydrate digestion speed (Venou et al., 2003).

Smaller nutrient particles from food processes facilitate digestion and absorption of carbohydrates and the proper action of amylase (Moura et al., 2007). Then, nutrients would be promptly available to digestive process, reducing the gastrointestinal transit. Furthermore, the cooking from extrusion procedure

Table 2. Gastrointestinal transit time (GITT) of diets in pacu fed two levels of carbohydrates (40 and 50\%) and lipids (4 and $8 \%$ ) under two diet processing (pelletization or extrusion) ${ }^{(1)}$.

\begin{tabular}{lc}
\hline $\begin{array}{l}\text { Dietary level } \\
\left(\mathrm{g} \mathrm{kg}^{-1}\right)\end{array}$ & GITT \\
\hline Carbohydrate & $16.08 \pm 1.09$ \\
400 & $15.66 \pm 1.05$ \\
500 & \\
Lipid & $16.16 \pm 1.01$ \\
40 & $15.58 \pm 0.84$ \\
80 & \\
Processing & $16.50 \pm 0.67 \mathrm{a}$ \\
Pelletization & $15.25 \pm 0.58 \mathrm{~b}$ \\
Extrusion & \\
\hline p-value (Anova) & $0.54^{\mathrm{ns}}$ \\
Carbohydrate levels & $1.06^{\mathrm{ns}}$ \\
Lipid levels & $4.89^{*}$ \\
Processing & $2.63^{\mathrm{ns}}$ \\
Carbohydrate x lipid & $2.63^{\mathrm{ns}}$ \\
Carbohydrate x processing & $0.02^{\mathrm{ns}}$ \\
Lipid x processing & $1.76^{\mathrm{ns}}$ \\
Carbohydrate x lipid x processing & \\
\hline
\end{tabular}

${ }^{(1)}$ Mean \pm standard deviation $(n=3)$ followed by equal letters, in the

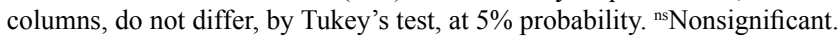
*Significant at $5 \%$ of probability. can also breakdown some molecules, facilitating the amylase action and altering the speed of absorption (Sartorelli \& Cardoso, 2006). Such difference has also been attributed to different degrees of chemical and physical modifications, as a consequence of high-extrusion temperature and pressure.

In the present study, to adjust nutrient levels in the experimental diets, it was necessary to increase the fiber content of some of them. Fiber content influences the GITT of several fish species. However, the observed variations in fiber diets can be considered small for P. mesopotamicus. Abimorad \& Carneiro (2007), studied pacu and observed that the inclusion of $18 \%$ fiber has not declined digestibility. In its natural habitat, pacu ingests much diversified feed, varying its sources with the seasons. The stomach contents of pacu consists mainly of leaves, plant residues, and little fish, or mollusk, or crustacean remains, showing that it is a herbivore fish with a predominantly frugivorous-feeding behavior. Fiber is a straightly linked factor to digestibility in addition to the food transit time. In the present formulations, fiber variation was unavoidable. However, studies on the digestibility and transit time of Colosoma macropomum depicted no changes in the transit time, due to inclusion of fiber from seed and fruit (Silva et al. 2003). Those

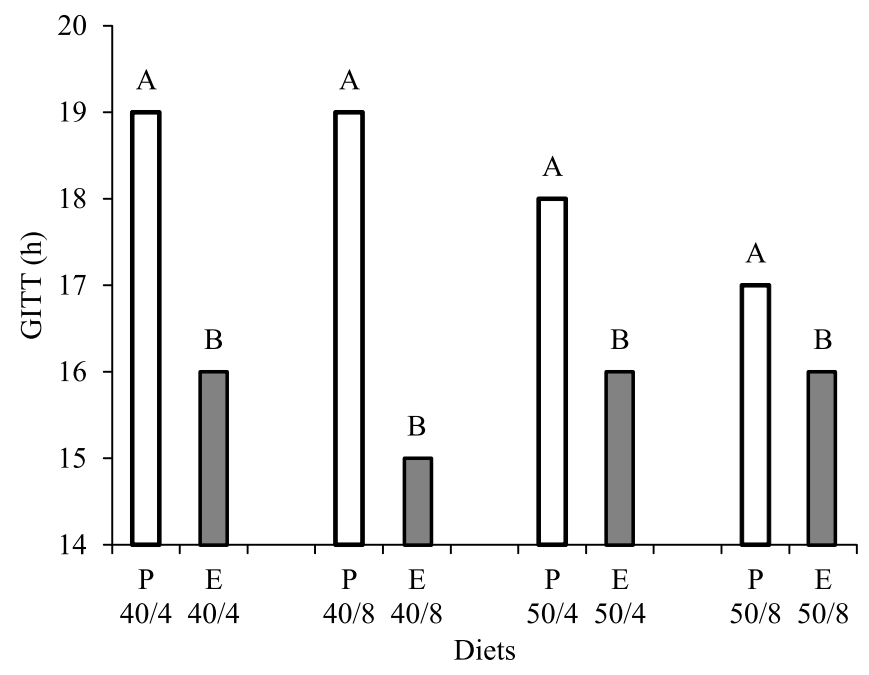

Figure 1. Gastrointestinal transit time (GITT) of diets in pacu fed two levels of carbohydrates (40 and 50\%) and lipids (4 and $8 \%$ ) under two diet processing: pelletization $(\mathrm{P})$; or extrusion $(\mathrm{E})$. Means $(\mathrm{n}=3)$ followed by equal letters do not difer by Tukey's test, at $5 \%$ of probability. 
observations must be taken into account, particularly, if considering that fiber content varied between 2.3$21.2 \%$. Fiber levels are supposed do not interfere on the permanence time of food in the digestive tract of fish with a frugivorous-feeding behavior. This should be an adaptive trait of the species feeding habit as living in the wild.

Modulation patterns of GITT regression analyses were dependent on the dietary carbohydrate for pelletized diets, and dietary lipid for extruded diets (Figure 2). In such concern, the GITT values for extruded diets, either at 40 or $50 \%$ carbohydrate, were fitted to a linear equation at $4 \%$ lipid and to a cubic equation model at $8 \%$ lipid. Otherwise, GITT values for pelletized diets, either at 4 or $8 \%$ lipids, were fitted to a quadratic equation model at $40 \%$ carbohydrate and to a cubic equation model at $50 \%$ carbohydrate.
Such differences above depicted should be attributed to different nutrient availability as a consequence of extrusion. Starch processing brings differences to absorption and fecal stability (Amirkolaie, 2013) affecting the digestion process. In addition, some factors could interfere in the digestive tract motility and gastric emptying time, depending on the ingested content type, volume, osmolality, acidity, and content of fats, proteins, and carbohydrates (Firman et al., 2000). Association of carbohydrate and lipid increased digestibility to Dicentrarchus labrax (Messina et al., 2013).

Cubic equations obtained from the polynomial regression analysis for both the extruded and the pelletized diets, containing 8\% lipids, showed fish adaptation because of the better use of the diets (Figure 2 $\mathrm{B}$ and D). From the present data, it is supposed that
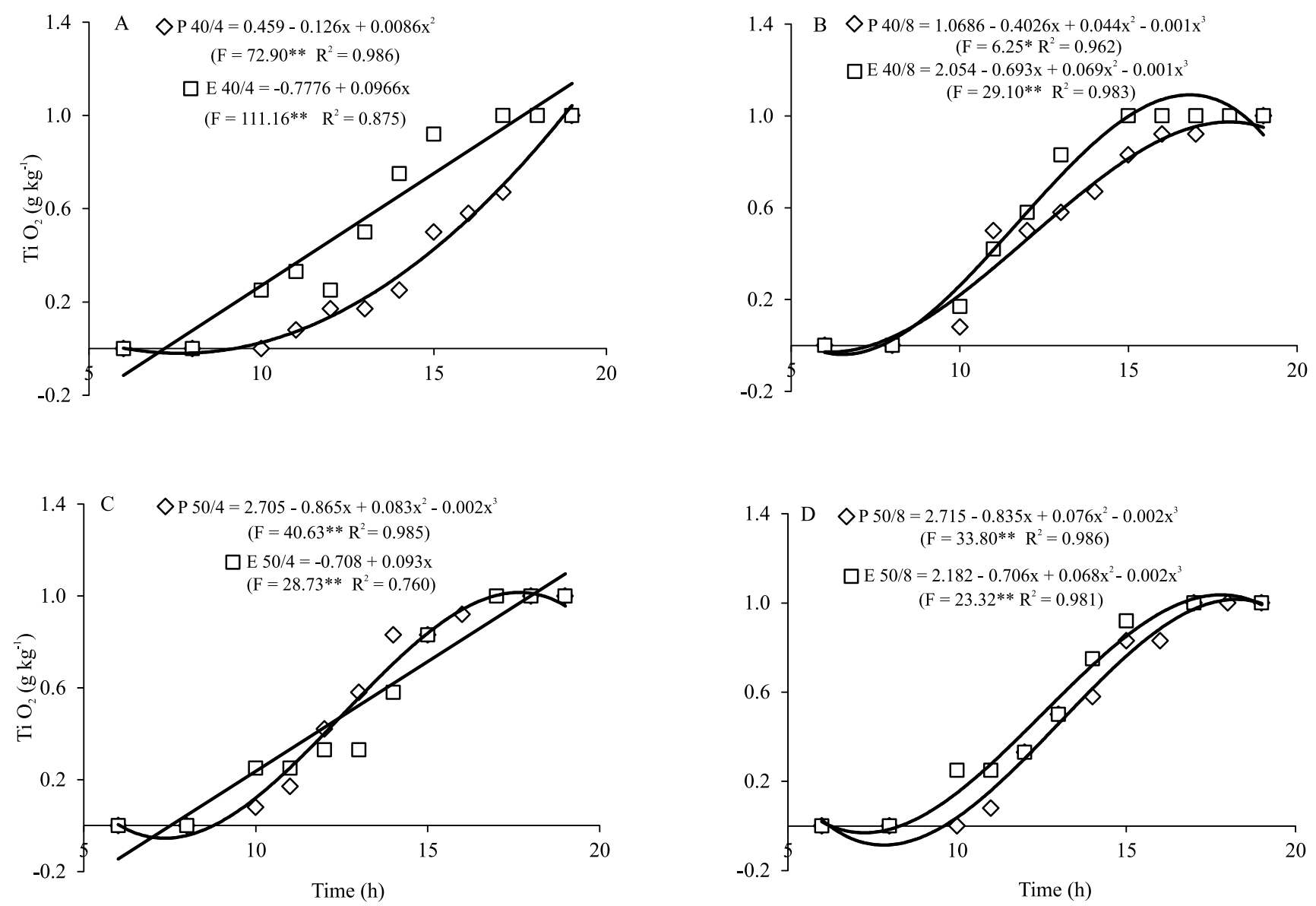

Figure 2. Modulation of gastrointestinal transit time (GITT) of diets in pacu fed two levels of carbohydrates (40 and $50 \%$ ) and lipids (4 and 8\%) under two diet processing: pelletization $(\mathrm{P})$ or extrusion $(\mathrm{E})$. Values are expressed as mean ( $\mathrm{n}=3$ ). 
diets with high-lipid levels are retained in the stomach for longer periods of time, stimulating cholecystokinin (CCK) production, which reduces the gastric motility (Meurer et al., 2002). Some hormones have a role in gastrointestinal motility regulation, such as gastrin and CCK (Melo et al., 2007). The production of CCK is related to the contents of bolus. Among several roles, CCK stimulates the bile release and reduces the gastric emptying, ensuring fat emulsification (Hojo et al., 2007).

In the extruded diets, the GITT fitted to a linear equation (Figure $2 \mathrm{~A}$ and $\mathrm{C}$ ). The misappropriate use of carbohydrates can result in increase of digestion viscosity, impairing the enzyme diffusion and substrate transport, as well as the transport of biliary salts and micelles into the gastrointestinal tract (Bomfim \& Lanna, 2004). Nevertheless, the use of gelatinized starch, originated from extrusion process, showed a positive correlation with the nutrient levels in the diet (Zhao et al., 2013).

Some mathematic models have been proposed to describe the gastric emptying in many fish species, such as in $S$. aurata, for which the GITT profile is adjusted to an exponential curve (Venou et al., 2003), whereas for Pseudoplatystoma corruscans it is adjusted to a cubic equation (Mayumeoshiro et al., 2012). GITT's mathematical profile is related to the excretion curve (Kitagima \& Fracalossi, 2010) and to the particular flow of food into a given segment of the digestive tract (Oliveira et al., 2007). However, it is worth emphasizing that these adaptations are related to the chyme fluidity in the digestive tract, which depends on the diet composition and on the amount of ingested food. These variables may change from one study to another. Chyme fluidity also depends on gastric secretions and the degree of digestion in the digestive tract (Kitagima \& Fracalossi, 2010).

\section{Conclusions}

1. Values for gastrointestinal transit time (GITT) of pacu are directly influenced by extrusion or pelletization in diet processing.

2. Fish fed with extruded diets show differentiated GITT modulations in relation to lipid levels in the diet.

3 . The use of extruded diets, with high levels of inclusion of lipid and carbohydrate sources is promising for pacu.

\section{Acknowledgements}

To Fundação de Amparo à Pesquisa do Estado de São Paulo (Fapesp, 04/07081-7), for scholarships granted.

\section{References}

ABIMORAD, E.G.; CARNEIRO, D.J. Digestibility and performance of pacu (Piaractus mesopotamicus) juveniles - fed diets containing different protein, lipid and carbohydrate levels. Aquaculture Nutrition, v.13, p.1-9, 2007. DOI: 10.1111/j.13652095.2007.00438.x.

ABIMORAD, E.G.; CARNEIRO, D.J. Métodos de coleta de fezes e determinação dos coeficientes de digestibilidade da fração protéica e da energia de alimentos para o pacu, Piaractus mesopotamicus (Holmberg, 1887). Revista Brasileira de Zootecnia, v.33, p.11011109, 2004. DOI: 10.1590/S1516-35982004000500001.

AMIRKOLAIE, A.K. The effect of feed ingredients on the settling velocity of feces in tilapia (Oreochromis niloticus L.). Iranian Journal of Fisheries Sciences, v.12, p.484-489, 2013.

BOMFIM, M.A.D.; LANNA, E.A.T. Fatores que afetam os coeficientes de digestibilidade nos alimentos para peixes. Revista Eletrônica Nutritime, v.1, p.20-30, 2004.

BOOTH, M.A.; MOSES, M.D.; ALLAN, G.L. Utilisation of carbohydrate by yellowtail kingfish Seriola lalandi. Aquaculture, v.376-379, p.151-161, 2013. DOI: 10.1016/j. aquaculture.2012.11.024.

DIAS-KOBERSTEIN, T.C.R.; CARNEIRO, D.J.; URBINATI, E.C. Tempo de trânsito gastrintestinal e esvaziamento gástrico do pacu (Piaractus mesopotamicus) em diferentes temperaturas de cultivo. Acta Scientiarum: Animal Sciences, v.27, p.413-417, 2005. DOI: $10.4025 /$ actascianimsci.v27i3.1219.

FABREGAT, T.E.H.P.; RODRIGUES, L.A.; NASCIMENTO, T.M.T. do; URBINATI, E.C.; SAKOMURA, N.K.; FERNANDES, J.B.K. Efeito da fonte de fibra no trânsito gastrointestinal e digestibilidade do pacu (Piaractus mesopotamicus). Revista Acadêmica de Ciências Agrárias e Ambiental, v.9, p.279-287, 2011.

FIRMAN, C.M.G.; COSTA, M.M.B.; COSTA, M.L.; LEMME, E. Avaliação qualitativa e quantitativa do esvaziamento gástrico através do método videofluoroscópico. Arquivos de Gastroenterologia, v.37, p.81-88, 2000. DOI: 10.1590/S0004-28032000000200003.

FURUKAWA, A.; TSUKAHARA, H. On the acid digestion method for the determination of chromic oxide as an index substance in the study of digestibility of fish feed. Bulletin of the Japanese Society of Scientific Fisheries, v.32, p.502-506, 1976. DOI: 10.2331/ suisan.32.502.

GONZÁLEZ-FÉLIX, M.L.; DAVIS, D.A.; ROSSI JUNIOR, W.; VELAZQUEZ, M.P. Evaluation of apparent digestibility coefficient of energy of various vegetable feed ingredients in Florida pompano, Trachinotus carolinus. Aquaculture, v.310, p.240-243, 2010. DOI: 10.1016/j.aquaculture.2010.10.016. 
HOJO, V.E.S.; MELO, J.M.; NOBRE, L.N. Alterações hormonais após cirurgia bariátrica. Revista Brasileira de Nutrição Clínica, v.22, p.77-82, 2007.

HONORATO, C.A.; NUNES, C. da S.; ALMEIDA, L.C. de; CARRILHO, E.N.V.M.; MORAES, G. Digestibilidade de dietas peletizadas e extrusadas para o pacu: quantificação do óxido de cromo. Revista Acadêmica de Ciências Agrárias e Ambientais, v.10, p.269-275, 2012. DOI: 10.7213/academica.7712.

HORWITZ, W. (Ed.). Official methods of analysis of AOAC International. $17^{\text {th }}$ ed. Gaithersburg: AOAC International, 2000. $1141 \mathrm{p}$.

KITAGIMA, R.E.; FRACALOSSI, D.M. Validation of a methodology for measuring nutrient digestibility and evaluation of commercial feeds for channel catfish. Scientia Agricola, v.67, p.611-615, 2010. DOI: 10.1590/S0103-90162010000500016.

KUBTIZA, F. Nutrição e saúde no cultivo de tilápia. Panorama da Aquicultura, v.21, p.14-23, 2013.

MAYUMEOSHIRO, F.; FRAGA, T.L.; HONORATO, C.A. Tempo de trânsito gastrointestinal do pintado (Pseudoplatystoma sp.). Journal of Agronomic Sciences, v.1, p.128-138, 2012.

MELO, U.P. de; PALHARES, M.S.; FERREIRA, C. Íleo adinâmico em equinos: fisiopatologia e tratamento. Arquivos de Ciências Veterinárias e Zoologia da Unipar, v.10, p.49-58, 2007.

MESSINA, M.; PICCOLO, G.; TULLI, F.; MESSINA, C.M.; CARDINALETTI, G.; TIBALDI, E. Lipid composition and metabolism of European sea bass (Dicentrarchus labrax L.) fed diets containing wheat gluten and legume meals as substitutes for fish meal. Aquaculture, v.376-379, p.6-14, 2013. DOI: 10.1016/j. aquaculture.2012.11.005.

MEURER, F.; HAYASHI, C.; BOSCOLO, W.R. Fibra bruta para alevinos de tilápia do Nilo (Oreochromis niloticus, L). Revista Brasileira de Zootecnia, v.32, p.256-261, 2003. DOI: 10.1590/ S1516-35982003000200002.

MEURER, F.; HAYASHI, C.; BOSCOLO, W.R.; SOARES, C.M. Lipídeos na alimentação de alevinos revertidos de tilápia do nilo (Oreochromis niloticus, L.). Revista Brasileira de Zootecnia, v.31, p.566-573, 2002. DOI: 10.1590/S1516-35982002000300005.

MOURA, G. de S.; OLIVEIRA, M.G.A.; LANNA, E.T.A.; MACIEL JUNIOR, A.; MACIEL, C.M.R.R. Desempenho e atividade de amilase em tilápias-do-nilo submetidas a diferentes temperaturas. Pesquisa Agropecuária Brasileira, v.42, p.1609-1615, 2007. DOI: 10.1590/S0100-204X2007001100013.

OLIVEIRA, K. de; COSTA, C.; FAUSTINO, M.G.; GASQUE, V. da S.; SANTOS, V.P. dos; LIMA, M.N.; NASCIMENTO FILHO, V.F. do; ABDALLA, A.L. Valor nutritivo e estudo cinético do trato digestivo de dietas contendo grãos secos ou ensilados de sorgo de baixo e alto tanino para eqüinos. Revista Brasileira de Zootecnia, v.36, p.1809-1819, 2007. DOI: 10.1590/ S1516-35982007000800014.
PEREIRA, J.C.; RIBEIRO, M.D.; VIEIRA, R.A.M.; PACHECO, B.M. Avaliação de modelos matemáticos para o estudo da cinética de passagem de partículas e de fluidos por bovinos em pastagem recebendo suplementos contendo diferentes níveis de proteína não-degradável no rúmen. Revista Brasileira de Zootecnia, v.34, p.2475-2485, 2005. DOI: 10.1590/S1516-35982005000700036.

SARTORELLI, D.S.; CARDOSO, M.A. Associação entre carboidratos da dieta habitual e diabetes mellitus tipo 2: evidências epidemiológicas. Arquivos Brasileiros de Endocrinologia e Metabologia, v.50, p.415-426, 2006. DOI: 10.1590/ S0004-27302006000300003.

SILVA, J.A.M. da; PEREIRA FILHO, M.; OLIVEIRA-PEREIRA, M.I. de O. Frutos e sementes consumidos pelo tambaqui, Colossoma macrompum (Cuvier, 1818) incorporados em rações. Digestibilidade e velocidade de trânsito pelo trato gastrointestinal. Revista Brasileira de Zootecnia, v.32, p.1815-1824, 2003. DOI: 10.1590/S1516-35982003000800003.

VENOU, B.; ALEXIS, M.N.; FOUNTOULAKI, E.; NENGAS, I.; APOSTOLOPOULOU, M.; CASTRITSI-CATHARINOU, I. Effect of extrusion of wheat and corn on gilthead sea bream (Sparus aurata) growth, nutrient utilization efficiency, rates of gastric evacuation and digestive enzyme activities. Aquaculture, v.225, p.207-223, 2003. DOI: 10.1016/S0044-8486(03)00290-4.

VIEIRA, J.S.; LOGATO, P.V.R.; RIBEIRO, P.A.P.; FREITAS, R.T.F. de; FIALHO, E.T. Efeito do processamento do milho sobre o desempenho e composição de carcaça de piaba (Leporinus friderici) criada em tanques-rede. Ciência e Agrotecnologica, v.29, p.453-458, 2005. DOI: 10.1590/S1413-70542005000200025.

WENK, C. The role of dietary fibre in the digestive physiology of the pig. Animal Feed Science and Technology, v.90, p.21-33, 2011. DOI: 10.1016/S0377-8401(01)00194-8.

YANG, N.; LIU, Y.; ASHTON, J.; GORCZYCA, E.; KASAPIS, S. Phase behaviour and in vitro hydrolysis of wheat starch in mixture with whey protein. Food Chemistry, v.137, p.76-82, 2013. DOI: 10.1016/j.foodchem.2012.10.004.

YOUNG, A.; MORRIS, P.C.; HUNTINGFORD, F.A.; SINNOTT, R. Replacing fish oil with pre-extruded carbohydrate in diets for Atlantic salmon, Salmo salar, during their entire marine grow-out phase: effects on growth, composition and color. Aquaculture, v.253, p.531-546, 2006. DOI: 10.1016/j. aquaculture.2005.08.006.

ZHAO, Y.; LIU, X.; WANG, J.; ZHANG, S. Effects of anionic structure on the dissolution of cellulose in ionic liquids revealed by molecular simulation. Carbohydrate Polymers, v.94, p.723-730, 2013. DOI: 10.1016/j.carbpol.2013.02.011.

ZONGJIA, J.C.; HARDY, R.W. Effects of extrusion processing of feed ingredients on apparent digestibility coefficients of nutrients for rainbow trout (Oncorhynchus mykiss). Aquaculture Nutrition, v.9, p.77-83, 2003. DOI: 10.1046/j.1365-2095.2003.00226.x.

Received on April 7, 2014 and accepted on October 24, 2014 